\title{
実システムにおける油圧サイレンサの挿入損失特性*
}

\author{
小 嶋 英 一*1, 寺 沢 達 士*2 \\ 伊藤 威一郎*2, 一 柳 隆 義*2
}

\section{Insertion Loss Characteristics of Hydraulic Silencers in Real Systems}

\author{
Eiichi KOJIMA*3, Tatsushi TERASAWA, \\ Iichirou ITO and Takayoshi ICHIYANAGI \\ *33 Kanagawa University, Dept. of Mechanical Engineering, \\ 3-27 1, Rokkakubashi, Kanagawa-ku, Yokohama, 221-8686 Japan
}

\begin{abstract}
The pulsation attenuation capabilities of hydraulic silencers in real systems are investigated theoretically and experimentally in terms of the insertion loss characteristics, taking the every important circuit-design factors including the pump and the load into consideration, so as to develop an useful CAE design tool for reducing the system audible noise level through the use of a fluidborne vibration control technique. Particular attention has been paid to the theoretical determination of the optimum insertion location where the potential attenuation capability of silencer can be brought out maximally. Theoretical model of the insertion loss characteristics is improved and validated by comparison with many experimental results obtained over the wide test conditions changing the insertion location variously for the different two branch-connection types of silencers under the different two load conditions. Additionally, a new expression for the insertion loss characteristics for the branch-connection type of silencer is proposed which makes the physical elucidation of its complex characteristics easy and help to search for the optimum insertion location efficiently. The simulated results of the insertion loss characteristics from the present theoretical model agree with the experimental results with sufficient accuracy for practical use up to around 5th harmonic (up to around $1.5 \mathrm{kHz}$ ) of the pump-induced harmonic pressure pulsations.
\end{abstract}

Key Words: Fluid Power System, Pressure Pulsation, Fluid-Borne Noise, Silencer, Side-Branch, Insertion Loss, Transmission Loss, Attenuation Characteristics, Noise Reduction

\section{1. 緒言}

油圧装置騒筸の主たる原因が油压ポンプの吐出し流 量脈動によって誘起される管路内の压力脈動による流 体伝ぱ騒音であることはよく知られている。特に，压 力脈動によって励振される騒音放射面を多くもつ建設 機械や射出成形機などの大形の油圧システムでは, 騷 音の全音響パワーに占める流体伝ぱ騒音の寄与率が極 めて高い.したがって，このような大形のシステムで は, 油压ポンプ端で発生した压力脈動の下流への伝ぱ を防いで装置騒音を低減させるために，王力脈動の伝 ぱ経路内にサイレンサ(脈動吸収器)を挿入する対策が 広く用いられている.

従来，油圧サイレンサの減衰性能を評価するための 特性值として, 音響〉ィル夕のそれと同じく, 透過損 失 (Transmission Loss：TL) と挿入損失 (Insertion Loss：IL)の二つの值が用いられている(1).この中,

* 原稿受付 1998 年 11 月 26 日

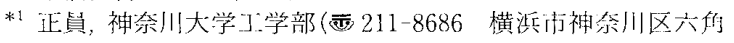
橋 3-27-1).

*2 神条川大学大学院.

E-mail : kojima@cc.kanagawa u.ac.jp
透過損失は設置(洀入)するシステムの特性にはよらな いサイレンサ固有の特性值であるが，サイレンサの出 口端が無反射(換言すれば，サイレンサ下流側管路が 一様で無限に長い)という特別な条件の下での值であ る、いっ沽う，抻入損失は，実システムに扔いてサイ レンサの設置により脈動がどの程度減衰するかを表す 設計者の最も知りたい最終的で実際的な性能評価量で あるが，サイレンサ自体のほかに負荷を含むサイレン サ下流側管路と脈動源を含むサイレンサ上流側管路 ${ }^{(2)}$ の脈動伝達特性にも依存する極めて複雑な特性を示 す.そのため, 例えば700 $800 \mathrm{~Hz}$ 程度以上の高周波 域ではポンプ内吐出し通路の脈動伝達特性(換言すれ ば，ポンプの内部インピーダンスの周波数特性）も扦 入損失に支配的に影響するにもかかわらず，従来の研 究は実システムに扔けるこのような主要な因子のいく つかが欠落している特別な条件の下での解析であ $り^{(3)(4)}$ ，設計者が実際に利用できるような挿入損失特 性に関する詳しい研究は発表されておらない。

本研究は, 油圧サイレンサによる低脈動油圧回路の 設計や使用する回路に最も適合する油圧サイレンサの 設計などを支援するコンピュータシミュレーションプ 
ログラムを開発することを究極の目的に，ポンプの脈 動源特性など実システムにおける主要な因子をすべて 考慮して挿入損失特性を理論と実験により解析してい る.なお，本研究では，任意の油压回路と任意の分岐 接続形サイレンサの組合せに対して，挿入損失特性を 統一的かつ物理的に明りょうに説明できる新なな挿入 損失の表示式を提示している.

\section{2. 記号}

本論文で使用するおもな記号は以下のとおりであ る.

$[\boldsymbol{a}]$ ：サイレンサ上流側管路の伝達マトリックス

$[\boldsymbol{b}]$ : ポンプケーシング内吐出し通路を含むサイレ ンサ上流側管路の伝達マトリックス

$c:$ 作動油中の音速

$f:$ 脈動周波数

$I L$ : 挿入損失 $[$ 式 (1)を参照 $]$

$K: Z_{r}$ に対する $Z_{e}$ の複素比 [式 $(21)$ を参照]

$\bar{K}: K$ の振幅比

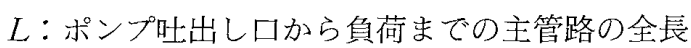

$l_{1}$ : サイレンサ上流側管路の長さ

$l_{2}$ :サイレンサ下流側管路の長さ

$l_{3}:$ ポンプケーシング内吐出し通路の等価長さ

$P:$ 圧力脈動

$Q:$ 流量脈動

$Q_{s}:$ ポンプ昍出し流量脈動(標準モデルにおける)

$Q_{s}^{*}$ : ポンプ吐出し流量脈動(修正モデルにお污る)

$r:$ 管の内半径

$s:$ ラプラス演算子

$[T]$ ：サイレンサの伝達マトリックス

$T L ：$ 透過損失

$x$ : ポンプ吐出しロから測ったサイレンサの挿入 位置 $\left(=l_{1}\right)$

$Z_{c}:$ 管路の特性インピーダンス

$Z_{e}$ : サイレンサ挿入位置での主管路の合成(並列) インピーダンス

$Z_{L}$ ：サイレンサ出口端から負荷側を見た下流側管

路のインピーダンス

$Z_{p}$ :サイレンサ入口端から脈動源側を見た上流側

管路のインピーダンス

$Z_{r}$ : 分岐形サイレンサの入ロインピーダンス

$Z_{s}:$ ポンプの内部インピーダンス

$Z_{T}:$ 負荷 (管路終端)インピーダンス

$\beta$ : 波動伝ぱ係数

$\rho:$ 作動油の密度

$\theta: K \circlearrowleft$ 位相差 $\nu$ : 作動油の動粘度

\section{3. 油圧サイレンサの挿入損失に対する 理論モデルの導出}

実システムに打ける油压サイレンサの減衰性能は挿 入損失を求めることにより，適正に評価することがで きる。この挿入損失は，下流側管路の同一位置におけ るサイレンサ挿入前と插入後の圧力脈動 $P^{\prime}$ と $P$ の振 幅比をデシベル単位で表したものであり，次式によっ て定義される值である。

$$
I L=20 \log _{10}\left|\frac{P^{\prime}}{P}\right| \text {. }
$$

図 1 に油圧ポンプ吐出し管路の途中に油圧サイレン サを挿入した油圧回路を示す。ここで, 油圧ポンプの 脈動源は, (a) ポンプ吐出し口端に並列に内部インピ ーダンスを有する流量脈動源 (以後, 標準モデルと呼 ぶ）または(b)ポンプケーシング内吐出し通路の始端 にある流量脈動源(以後, 修正モデルと呼ぶ)のいずれ かでモデル化できる(5) (7).

初めに, 油圧ポンプの脈動源に畄 1(a)に示す標準 モデルを用いて実システムに扔けるサイレンサの挿入 損失の理論モデルを導出する。

サイレンサ上流側管路の流体波動に対して岡体管路 の非定常層流の一次元波動方程式が適用できると仮定 すると, 上流端の圧力脈動および流量脈動と下流端の 圧力脈動および流量脈動の関係は伝達マトリックス係 数 $[\boldsymbol{a}]$ を用いてラプラス領域で次式のように表せる.

$$
\left[\begin{array}{l}
P_{0} \\
Q_{0}
\end{array}\right]=\left[\begin{array}{cc}
\cosh \left(\beta l_{1}\right) & Z_{c} \sinh \left(\beta l_{1}\right) \\
\sinh \left(\beta l_{1}\right) / Z_{c} & \cosh \left(\beta l_{1}\right)
\end{array}\right]\left[\begin{array}{c}
P_{1} \\
Q_{1}
\end{array}\right] \cdots
$$

ここに, 波動伝ぱ係数 $\beta$ と特性インピーダンス $Z_{c}$ は 非定常層流抵抗の影響を表す複素係数 $\xi$ 用いて次

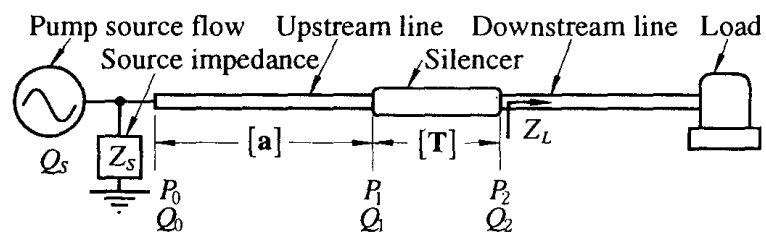

(a ) Standard model

Pump source flow

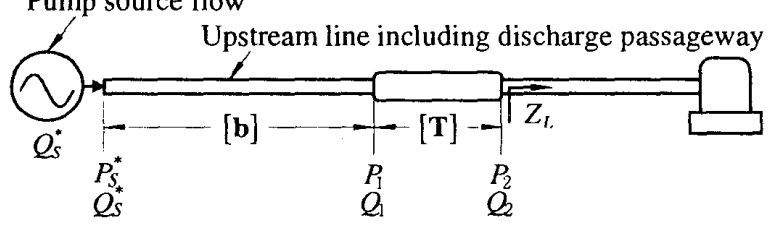

(b) Revised model

Fig. 1 Hydraulic circuits with a silencer inserted and typical models for pump pulsation source 
式のように与えられる(8).

$$
\begin{aligned}
& \beta=\frac{\xi}{c} s \\
& Z_{c}=\frac{\rho c \xi}{\pi r^{2}} \\
& \xi \cong 1+\sqrt{\frac{\nu}{r^{2} S}}+\frac{\nu}{r^{2} s}
\end{aligned}
$$

ポンプ吐出しロに扔ける流量の連続の式から次式が 得られる。

$$
Q_{0}=Q_{s}-\frac{P_{0}}{Z_{s}}
$$

サイレンサの入口㧍よび出口に扔ける圧力脈動と流 量脈動の関係は伝達マトリックス $[\boldsymbol{T}]$ を用いて次式 のように表せる。

$$
\left[\begin{array}{c}
P_{1} \\
Q_{1}
\end{array}\right]=\left[\begin{array}{ll}
T_{11} & T_{12} \\
T_{21} & T_{22}
\end{array}\right]\left[\begin{array}{c}
P_{2} \\
Q_{2}
\end{array}\right]
$$

ここに，伝達マトリックス係数 $T_{11} \sim T_{22}$ はシステ ムには独立なサイレンサ固有の特性值である。

サイレンサ出口端(すなわち, サイレンサ下流側管 路の入口端)の境界条件は次のようにインピーダンス の関係で表せる。

$$
Z_{L}=\frac{P_{2}}{Q_{2}}
$$

ここに, $Z_{L}$ はサイレンサ出口端から負荷側を見たイ ンピーダンスであり，下流側管路系のすべての構成要 素の脈動伝達特性(例光ば, 伝達マトリックス係数) と 負荷 (終端)インピーダンス $Z_{T}$ が何らかの方法(理論 または実験)で知れれば解析的に求められる(9).

以上の式( 2) 〜 (8) から, ポンプの吐出し流量脈動 $Q_{s}$ に起因するサイレンサ下流側管路の入口端の圧力 脈動 $P_{2}$ が $Q_{s}$ の関数として次の上うに求まる。

$$
P_{2}=\frac{Z_{s} Z_{L}}{\left(a_{11}+a_{21} Z_{s}\right)\left(T_{11} Z_{L}+T_{12}\right)+\left(a_{12}+a_{22} Z_{s}\right)\left(T_{21} Z_{L}+T_{22}\right)} Q_{s} .
$$

回路にサイレンサを挿入する前では， $T_{11}=T_{22}=1$ および $T_{12}=T_{21}=0$ であるので，そのときの下流側管路の入 口端の圧力脈動 $P_{2}^{\prime}$ 汢式 ( 9 ) から次のようになる。

$$
P_{2}^{\prime}=\frac{Z_{s} Z_{L}}{\left(a_{11}+a_{21} Z_{s}\right) Z_{L}+\left(a_{12}+a_{22} Z_{s}\right)} Q_{s}
$$

よって, 式 $(9)$ と(10)から, 式(1)で定義される㨂入損失として次式が導かれる.

$$
I L=20 \log _{10}\left|\frac{\left(a_{11}+a_{21} Z_{s}\right)\left(T_{11} Z_{L}+T_{12}\right)+\left(a_{12}+a_{22} Z_{s}\right)\left(T_{21} Z_{L}+T_{22}\right)}{\left(a_{11}+a_{21} Z_{s}\right) Z_{L}+\left(a_{12}+a_{22} Z_{s}\right)}\right| .
$$

次に, 油圧ポンプの脈動源に図 1(b)に示す修正モデルを用い, ポンプ内吐出し通路を吐出し管路と同じ特性イ ンピーダンスをもち，かつ，後述するポンプ内部インピーダンス $Z_{s}$ の周波数特性の共振周波数から定まる長さを もつ等価管路で近似すると, 式 $(9)$ 〜 (11) に相当する式として次式が得られる.

$$
\begin{aligned}
& P_{2}=\frac{Z_{L}}{b_{21}\left(T_{11} Z_{L}+T_{12}\right)+b_{22}\left(T_{21} Z_{L}+T_{22}\right)} Q_{S}^{*} \ldots \\
& P_{2}^{\prime}=\frac{Z_{L}}{b_{21} Z_{L}+b_{22}} Q_{s}^{*} \\
& I L=20 \log _{10}\left|\frac{b_{21}\left(T_{11} Z_{L}+T_{12}\right)+b_{22}\left(T_{21} Z_{L}+T_{22}\right)}{b_{21} Z_{L}+b_{22}}\right|
\end{aligned}
$$

ここに, $b_{11} \sim b_{22}$ は上述のポンプ内吐出し通路の等価一様真直管路を含むサイレンサ上流側管路の伝達マトリック 又係数であり, 式 (2)の $a_{11} \sim a_{22}$ と同じ形の式で与えられる.

なお，サイレンサ下流側管路内の圧力脈動の振幅はサイレンサ挿入前も挿入後に扔いても管路の位置によって変 化するが, 定在波比はいずれの場合も同じであるため, サイレンサ插入前・後の下流側管路の圧力脈動の振幅比を 表す扦入損失 $I L$ は管路の位置によらない值である，換言すれば, 式(11)と(14) は下流側管路のすべての位置で成 立つ式であることに注意すべきである。

さらに, ヘルムホルツ形共鳴器や閉鎖管サイドブランチのように主管路に分岐接続して設置する形式のサイレン サでは, 式 ( 7)の伝達マトリックス係数 $T_{11} \sim T_{22}$ はサイレンサの入ロインピーダンス $Z_{r}$ が与えられると次のよう に定まる。

$$
[\boldsymbol{T}]=\left[\begin{array}{ll}
T_{11} & T_{12} \\
T_{21} & T_{22}
\end{array}\right]=\left[\begin{array}{cc}
1 & 0 \\
1 / Z_{r} & 1
\end{array}\right]
$$

よって，分岐接続形のサイレンサに対しては，式(11)と式(14)は $Z_{r}$ を用いてそれぞれ式(16)および(17)のように も記述できる。 


$$
\begin{aligned}
& I L=20 \log _{10}\left|\frac{\left(a_{11}+a_{21} Z_{s}\right) Z_{r} Z_{L}+\left(a_{12}+a_{22} Z_{s}\right)\left(Z_{r}+Z_{L}\right)}{\left(a_{11}+a_{21} Z_{s}\right) Z_{r} Z_{L}+\left(a_{12}+a_{22} Z_{s}\right) Z_{r}}\right| \ldots \\
& I L=20 \log _{10}\left|\frac{b_{21} Z_{L} Z_{r}+b_{22}\left(Z_{r}+Z_{L}\right)}{Z_{r}\left(b_{21} Z_{L}+b_{22}\right)}\right| \ldots \ldots \ldots \ldots \ldots \ldots \ldots \ldots \ldots \ldots \ldots \ldots \ldots \ldots \ldots \ldots \ldots \ldots \ldots
\end{aligned}
$$

以上，サイレンサの挿入損失の一般式である式(11) または式(14)，あるいは分岐接続形サイレンサの挿入 損失に対する式(16)または(17) からわかるように，実 システムにおける挿入損失特性はサイレンサ, 脈動源 を含む上流側管路扔よび負荷を含む下流側管路系の脈 動伝達特性の複雑な相互作用に依存するため, たとえ 分岐接続形のサイレンサに対しても，これらの表式の ままでは種々の組合せに対して数値計算を行わない限 り，特性に及ぼす諸因子の定性的な影響すら知ること は難しい.

しかし，上式を次のような形 [後述する式(21)］に 書き換えて考えると，挿入損失特性に及ぼす諸因子の 影響を分岐接続形サイレンサとシステムの任意の組合 せに対して統一的かつ物理的に説明することが可能に なる。以下, 式(16)と（17）に代わる挿入損失の新しい 表示式 [注：挿入損失の定義そのものは式(1)と全く 同じである]を導出する.

図 2 に示すように，サイレンサの分岐接続部から見 た主管路の合成(並列)インピーダンス $Z_{e}$ は, 分岐接 続部から脈動源側を見た上流側管路のインピーダンス を $Z_{p}$ とすると次式で与えられる。

$$
\frac{1}{Z_{e}}=\frac{1}{Z_{p}}+\frac{1}{Z_{L}}
$$

ここに, $Z_{p}$ は図 $2(\mathrm{a})$ の標準モデルと(b)の修正モデ ルに対してそれぞれ次式のように与えられる.

$$
Z_{p}=\frac{a_{12}+a_{22} Z_{s}}{a_{11}+a_{21} Z_{s}}
$$

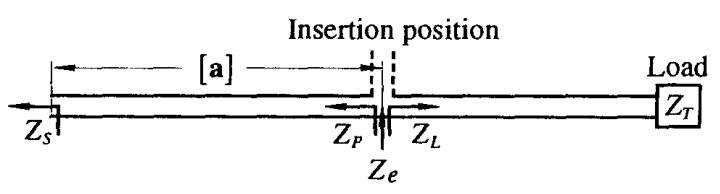

(a) Standard model

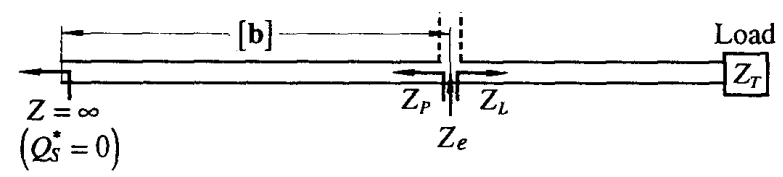

(b) Revised model

Fig. 2 Impedance representation of circuit and resultant impedance $Z e$ of the main line at the side-branch junktion

$$
Z_{p}=\frac{b_{22}}{b_{21}}
$$

式(18)と（19）を式(16)におょび式(18)と（20）を式 (17)に代入すると，眓 1 の（a）と（b)に示すいずれの ポンプ脈動源モデルに対しても, 分岐接続形サイレン サの挿入損失の表示式として新たに次式が導かれる。

$$
\begin{aligned}
I L & =20 \log _{10}\left|1+\frac{Z_{e}}{Z_{r}}\right| \\
& \equiv 20 \log _{10}\left|1+\bar{K} e^{j \theta}\right|
\end{aligned}
$$

すなわち, 分岐接続形サイレンサの挿入損失は, サイ レンサと主管路の組合せの種類によらず，サイレンサ の入ロインピーダンス $Z_{r}$ と分岐部に拈ける主管路の 合成インピーダンス $Z_{e}$ の複素比(振幅比: $\bar{K}$, 位相 差： $\theta$ )の関係のみで表せることがわかる.

\section{4. 実験解析と考察}

$\mathbf{4} \cdot \mathbf{1}$ 供試サイレンサ＼cjkstart供試サイレンサには図 3 に示す ( a ) 通常の $1 / 4$ 波長サイドブランチと (b) 著者 らの一人が開発した“可変共振モード形”と呼ぶサイ ドブランチの 2 種類のサイレンサを用いた。この中, 可変共振モード形サイドブランチは，䦥鎖管内に複数 個のチョーク形絞りを挿入し絞りの径と長さおよび分

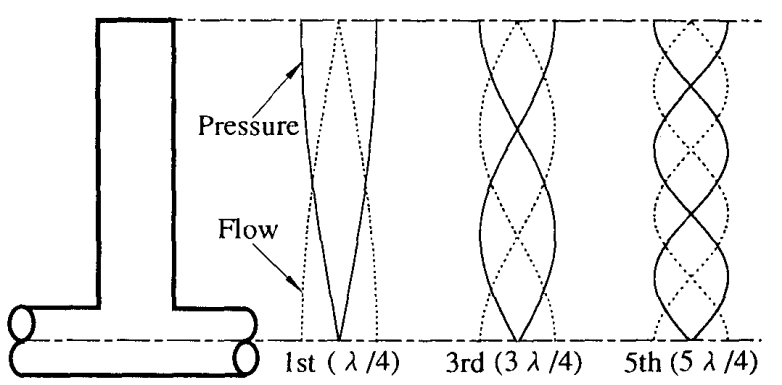

(a) Conventional quarter-wavelength side-branch resonator

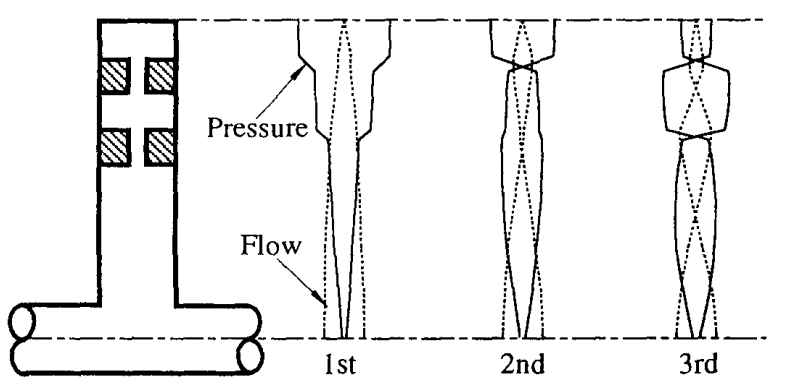

(b) Variable-resonance mode type side-branch resonator

Fig. 3 Schematic diagram of test silencers and their resonance mode-shapes 


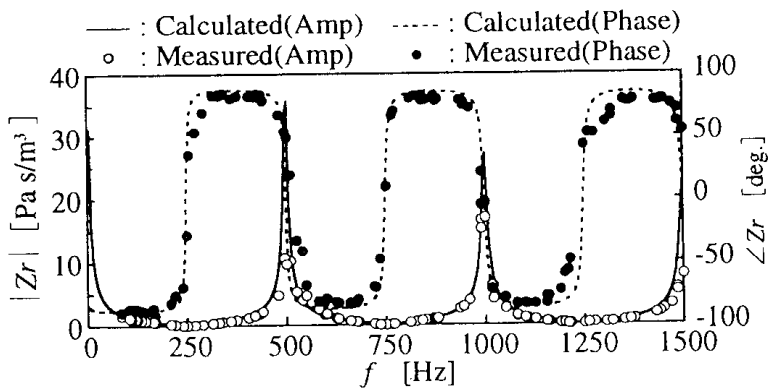

(a 1) Entry impedance

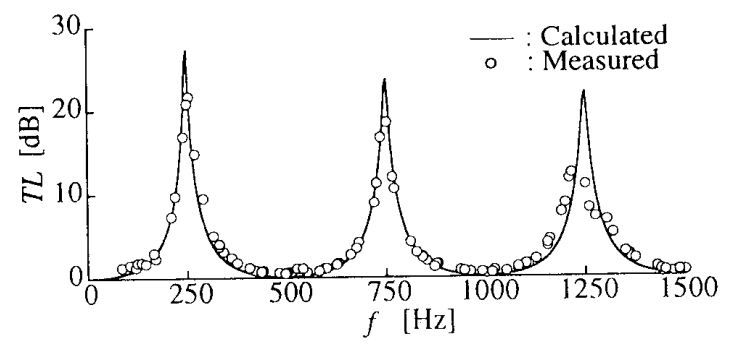

(a-2) Transmission loss

(a) Quarter wavelength side branch resonator

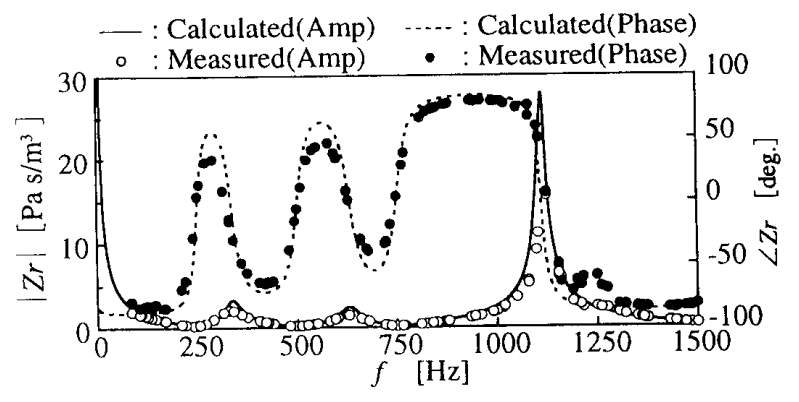

(b-1) Entry impedance

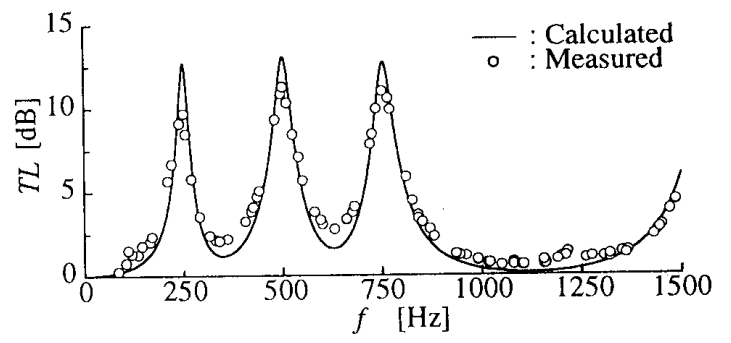

(b-2) Transmission loss

(b) Variable-resonance mode type side-branch resonator

Fig. 4 Measured and designed (calculated) entry impedance $Z r$ and transmission loss $T L$ of the test silencers

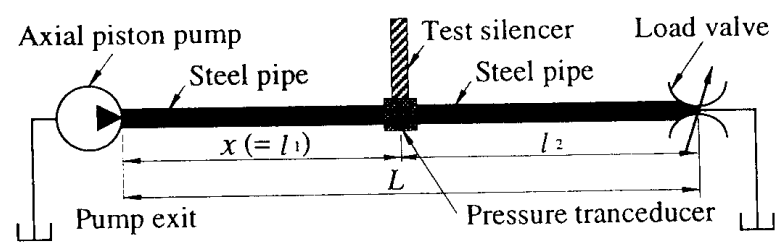

(a) Resistive impedance load

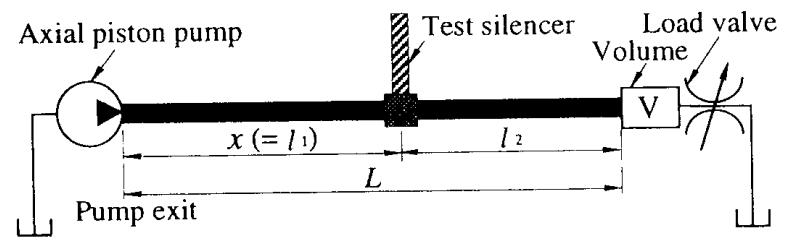

(b) Capacitive impedance load

Fig. 5 Test hydraulic circuits for insertion loss

割された閉鎖管部の長さを適切に調節することによ り, 複数個の共振モードを任意の周波数に設定できる ように考案されたものである(10).ただし供試したも のは指定した最低周波数の1, 2 扔よび 3 倍の周波数 に共振モードが現れるように設計されている。本研究 では，いずれのサイレンサも，最低共振周波数がポン プ誘起の圧力脈動の基本周波数の $250 \mathrm{~Hz}$ に一致する ように諸元が決められている。図 4 に“4 压力/2 シス テム法”(11)(12)より求めた両供試サイレンサの人口イ ンピーダンス $Z_{r}$ と透過損失 $T L$ 実測值と設計值 (計算值)を示す.

\section{$4 \cdot 2$ 試験油圧回路と試験方法 挿入損失解析用}

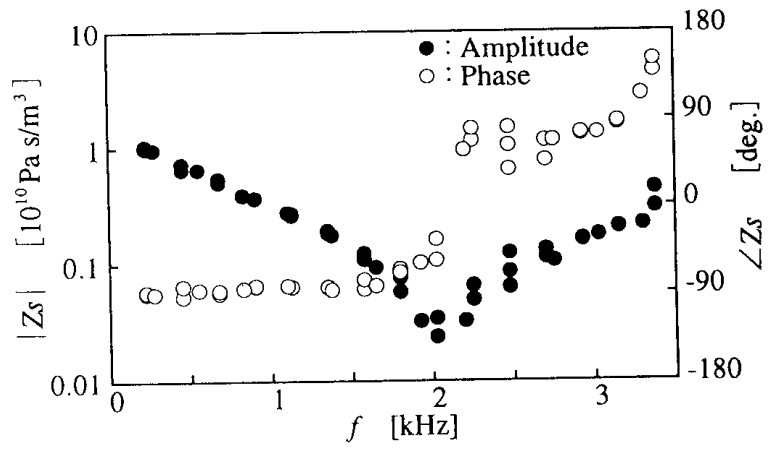

Fig. 6 Experimentally determined source impedance of the axial piston pump used in this tests

の試験油圧回路は, 図 5 に示すように,アキシャルピ ストンポンプ, 上流側管路, 供試サイレンサ, 下流側 管路抢よび弁負荷 [図 5(a)］または容量負荷 [図 5 (b)] 加ら構成されている. 試験油圧回路は比較的 単純であるが，挿入損失に影響する実システムの主要 な(基本的な)因子を寺べて含んでいる.

ポンプ吐出し口から負荷までの主管路の長さ $L$ は, 実システムを想定してサイレンサの挿入位置によら ず，(a ）の弁負荷では $L=2.05 \mathrm{~m} ，(b)$ の容量負荷で は $L=2.11 \mathrm{~m}$ の一定值に保持している. 換言すれば, サイレンサの挿入位置に応じて鋼管製の上流側管路と 下流側管路の長さ $l_{1}$ と $l_{2}$ を変えて実験を行っている。

図 6 は，著者の一人が開発した“2 左力/ 2 システム 法”(6)(7)により求めた脈動源である油圧ポンプの内部 
インピーダンス $Z_{s}$ の振幅と位相の測定值であり, 約 $2 \mathrm{kHz}$ に $1 / 4$ 波長モードの共振が現れていることが わかる、本研究では, 図1(a)の標準モデルを用いる 場合には $Z_{s}$ の測定值そのものを, 図 1(b)の修正モ デルを用いる場合には上の共振周波数 $f_{c}$ を基に $l_{c}=$ $c / 4 f_{c}$ の関係から得られる $l_{c} \simeq 0.163 \mathrm{~m}$ の長さの等価 管路の動特性を [具体的には, 式 (2)で $l_{1} \rightarrow l_{1}+l_{c} \equiv l_{3}$ として], 脈動源の波動伝ぱの特性値として用いてい る.

挿入損失の実験は, 脈動の基本周波数が $250 \mathrm{~Hz}$ に なるように 9 本ピストンのポンプを $1667 \mathrm{rpm}$ で運転 し，サイレンサの挿入位置をいろいろに変えて挿入 前・後の圧力脈動を下流側管路の入口端(詳しくは, 接続用ブロック)に設けた半導体圧力変換器で測定し, 次いでこれらをFFTでスペクトル分析し，式（1）加 ら各調和成分の捕入損失の実測値を求めている.

$4 \cdot 3$ 実験結果と考察 図 7 と 8 は，それぞれ $1 / 4$ 波長サイドブランチと可変共振モード形サイドブラン チの，（a）弁負荷と (b) 容量負荷に対する，指入損失 の実測值と修正モデルに基づく式(17)加算出した計 算値であり，脈動の各調和成分の隇衰とサイレンサ挿 入位置の関係を示したものである. 図 9 は標準モデル に基づく式(16)から算出した挿入損失の許算値と実測

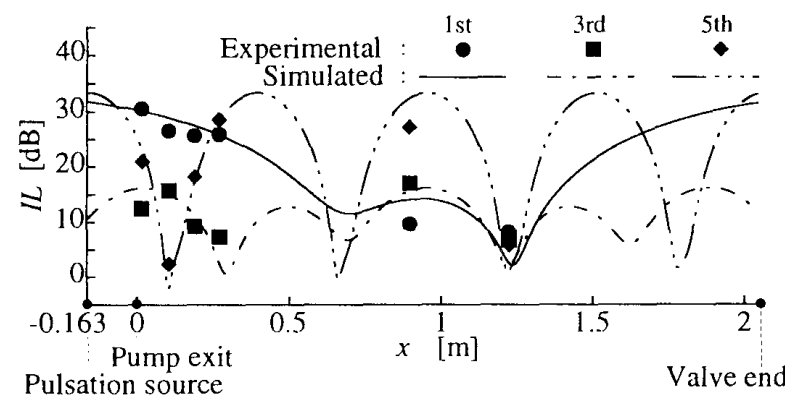

(a) Resistive impedance load

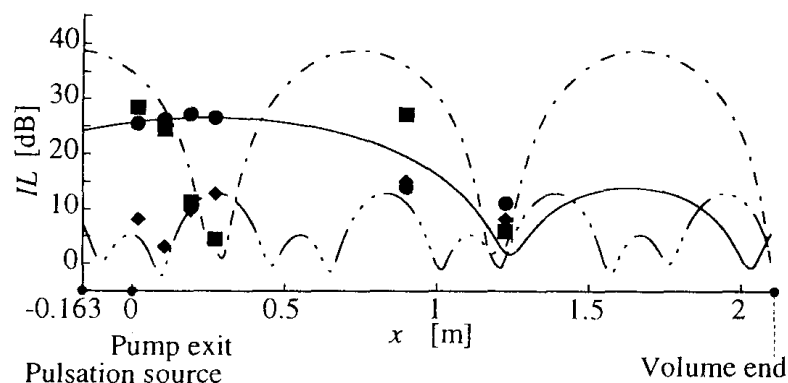

(b) Capacitive impedance load

Fig. 7 Experimental and simulated (based on the "revised model") results of the insertion loss of quarter-wavelength side-branch for (a) resistive and ( $b$ ) capacitive impedance load

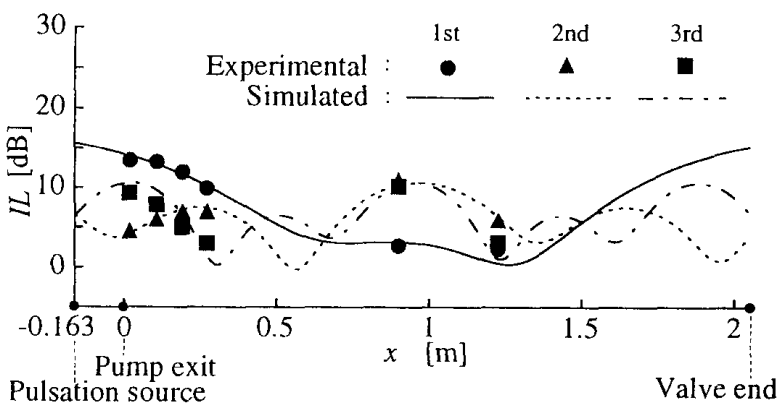

(a) Resistive impedance load

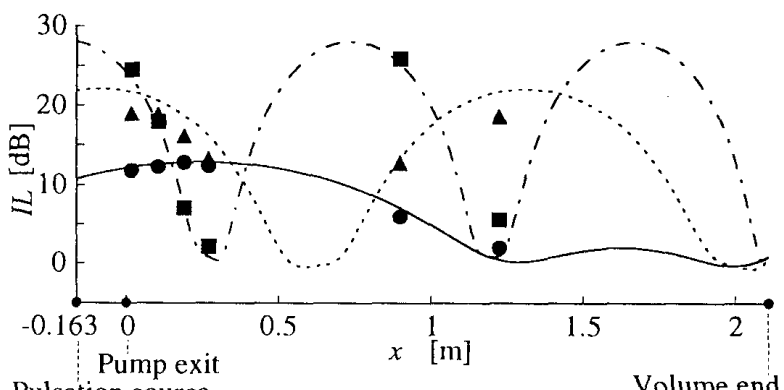

Pulsation source

(b) Capacitive impedance load

Fig. 8 Experimental and simulated (based on the "revised model") results of the insertion loss of variable-resonance mode type side-branch for (a) resistive and (b) capacitive impedance load

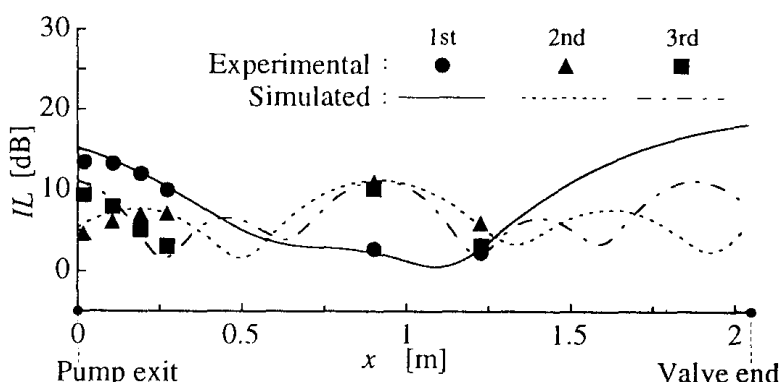

(a) Resistive impedance load

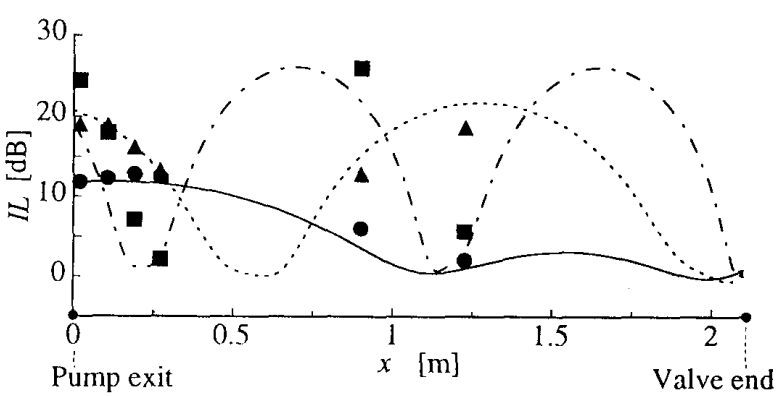

(b) Capacitive impedance load

Fig. 9 Experimental and simulated (based on the "standard model") results of the insertion loss of variable-resonance mode type side-branch for (a) resistive and (b) capacitive impedance load 
値を比較した例である。なお,式(16)と(17)の計算に 当たっては, $Z_{L}$ は負荷インピーダンス $Z_{T}$ (弁負荷で は $Z_{T}=2 P_{0} / Q_{0}$, 容量負荷では $Z_{T}=B / V_{S}, こ こ に$, $P_{0}$ : 定常圧力, $Q_{0}$ : 定常流量, $B$ : 作動油の体積弾性 係数, $V$ : 容器内の作動油の体積) と下流側管路の伝 達マトリックスから定まる(9)理論值を, $Z_{r}$ は図 4 に 示す実測值を, 伝達マトリックス係数 $a_{11} \sim a_{22}$ は式 (2)の理論值を, 伝達マトリックス係数 $b_{11} \sim b_{22}$ は 3 ・ 2 節で求めたポンプ内昍出し通路の等価管路を含む上 流側管路に対する式 (2) と等価な式の理論值を用い た。

図 7〜9の結果から次のような事柄が考察できる.

(i) ポンプ脈動源に対していずれのモデルを用い ても，負荷条件，サイレンサの種類および設置位置に 依らず，扦入損失の計算值は実測值と実用上十分な精 度で一致している。

（ii）挿入損失はサイレンサの脈動伝達特性のほか に, サイレンサの設置(插入) 位置と周波数に著しく依 存する。

（iii）両管路のいずれかが压力脈動の定在波の節 (node) となる位置，例えば閉口端に近い弁負荷の場合 には，上流側管路の脈動源端および下流側管路の負荷 端からそれぞれ $c / 4 f$ の奇数倍(例えば, 脈動の一次の $f=250 \mathrm{~Hz}$ の調和成分では $1440 /(4 * 250)=1.44 \mathrm{~m}$ の 奇数倍, 脈動の二次の $f=500 \mathrm{~Hz}$ の調和成分では $0.72 \mathrm{~m}$ の奇数倍) の位置で挿入損失は極小となる(減 衰性能が極端に低下寸る)。

(iv) 高周波域(通常の大きさのピストンポンプで は約 700〜 $800 \mathrm{~Hz}$ 以上)の調和成分に対しては, サイ レンサをポンプ吐出しロ近くに設置しても，この位置 が上流側管路の圧力脈動の定在波の節の近くになって しまい, 減衰効果はほとんど期待できない(後述する ように, サイレンサの設置により压力脈動がかえって 增幅されてしまうこともある).

（v）両管路ともに压力脈動の定在波の腹となる位 置, すなわち, 弁負荷の場合には脈動源端と負荷端か ら $c / 2 f$ 整数倍の位置近く(㛜密には, 後述する $Z_{e}$ が極大となる位置)で挿入損失は極大となる (高い減衰 性能が得られる).

（vi）高い減哀性能を得るためには，サイレンサを ポンプ吐出しロの極近く(可能ならば, ポンプ内吐出 し通路の始点近く)に設置し，しかも，下流側管路をサ イレンサ設㯰位置で压力脈動の定在波の腹になる(こ れが不可能ならば, 少なくとも節から十分離れてい る)長さにすることが望ましい.

次に，任意の油压システムにおける挿入損失特性の

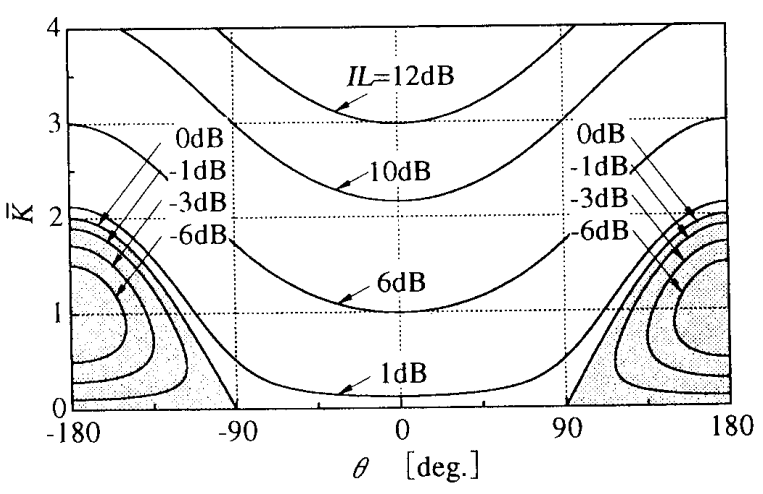

Fig. 10 Insertion loss with relations of $\bar{K}$ and $\theta$
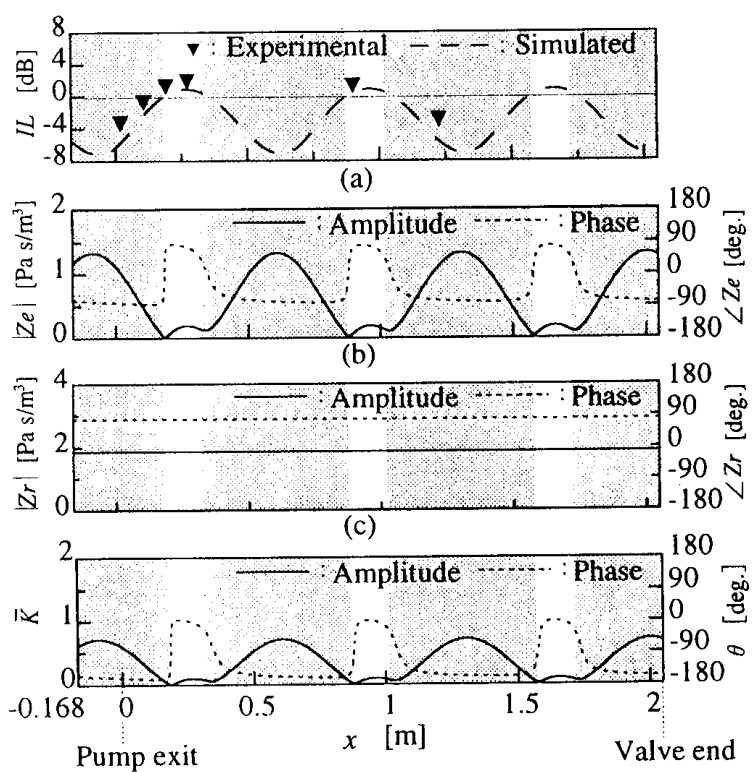

(d)

Fig. $11 \quad I L, Z e, Z r$ and $K$ of the variable-resonance mode type side-branch for 4 th harmonic of pressure pulsation relating to the insertion position $x$

大要を統一的かつ物理的に説明でき，またここれよ りサイレンサの最適挿入位置なども見通しよく探索で きるようにすることを目的に，前述した式(21)を用い て, サイレンサの入ロインピーダンス $Z_{r}$ とサイレン サ挿入位置に扔ける主管路の合成インピーダンス $Z_{e}$ の組合せ特性との関連において挿入損失特性を調べて みる。

図 10 は, 横軸に $\theta$, 縦軸に $\bar{K}$, パラメータに $I L を$ とって式(21)を図示したものである。この図は，あら ゆる種類の分岐接続形サイレンサと回路(システム)の 任意の組合せに対して適用できる插入損失の一般的な

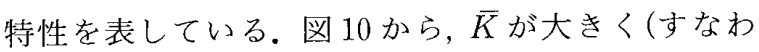
ち, $\left|Z_{r}\right|$ が小さく $\left|Z_{e}\right|$ が大きい)また $|\theta|$ が小さい(す なわち, $Z_{r}$ と $Z_{e}$ が同位相に近い)ほど高い挿入損失 
特性が得られること, $\bar{K}$ が 2 より小さくかつ $|\theta|$ が $\pi / 2$ より大きい場合には择入損失の值が負になりサイ レンサの挿入によってかえって圧力脈動が増幅してし まう可能性のあること等がわかる. 以下, サイレンサ の挿入によってかえって圧力脈動が增幅されてしまう 解析例を示す。

図 11 (a) は圧力脈動の 4 次 (本研究では, $1000 \mathrm{~Hz}$ ) の調和成分に対する供試可変共振モード形サイドブラ ンチの挿入損失特性を, 図 $11(\mathrm{~b}) \sim(\mathrm{d})$ はそれぞれこ の調和成分の周波数に対する $Z_{e}\left(\left|Z_{e}\right|\right.$ と $\left.\angle Z_{e}\right)$, $Z_{r}\left(\left|Z_{r}\right|\right.$ と $\left.\angle Z_{r}\right)$ 扝よび $K(\bar{K} と \theta)$ の值を, サイレン サの挿入位置 $x$ の関数として図示したものである. 図 11(a)から, サイレンサ插入位置がポンプ吐出しロ 近くの $x=0.02 \mathrm{~m}$ と $x=0.11 \mathrm{~m}$ の場合には, 挿入損 失は実測值㧍よび計算値ともに負になっていることが わかる。これは，これらの位置に扔いては，Zeと $Z_{r}$ の位相がそれぞれほぼー 11（b)，(c)参照]ために $\theta$ が $-\pi$ に近く,しかも $\bar{K}$ が $0.3 \sim 0.6$ と小さいために [図 $11(\mathrm{~d})$ 参照]，こ れらの挿入位置ではサイレンサと回路の組合せ条件が 図 11 の陰影部(ILが負になる領域) に宿ってしまうと いう理由によるためである。

な拉，通常の $1 / 4$ 波長サイドブランチの実システム への適用に当たっても，その挿入によって圧力脈動の 偶数次 (例えば, 2 次や 4 次)の調和成分がかえつて増 幅されてしまったり，あるいは本来は(潜在的には)減 衰効果のある奇数次(例元ば 3 次や 5 次) の調和成分が 満足に減衰されないことはしばしば経験することであ るが，これらの現象も上と同じ理由に基づくものであ り, 式(21)の関係(すなわち，図 10)を用いて統一的に 説明することができる.

\section{5. 結 言}

本報では，油圧サイレンサを用いた流体伝ぱ振動制 御により低脈動・低騒音の油圧システムを設計・開発 する際の基礎資料となる插入損失特性を, 油圧ポンプ の脈動源特性や負荷特性を含む実システムの主要な因 子をすべて考慮して理論と実験により解析し，特性に 及ぼす諸因子の影響を明らかにするとともに，分岐接 続形サイレンサと回路(システム)の任意の組合せに対 する挿入損失特性を統一的かつ物理的に説明できる新 しい挿入損失の表示式を提案した.

今後は, 前報(10) と本論文の解析結果を基に, 特定の 油压システムの指定された扱入位置において, 最高の 減衰性能を発揮できる可変共振モード形のサイドブラ ンチを開発したいと考える。

\section{文献}

(1) 例 え.ば, ISBN No 0-906085-49-7, Quieter Fluid Power Handbook, 33, BHRA.

（2）㲈尾誠一一小西忠孝・植田俊明・大熊昭二, 機論, 54-504, B (1988), 1953-1961.

(3) Bais, R. J. and Toet, G., Fifth Bath Int. Fluid Power Workshop, (1994), 138-154.

(4) Strunk, R. D., SAE Paper, No. 911759 (1991), 1-7.

(5) Edge, K. A. and Johnston, D. N., Proc. Instn Mech Engrs, Vol. 204 (1990), 33-46.

（6）小嶋英一, 油圧と筀気圧, 24-2 (1993), 269-274.

（7）小嶋英一・渡辺敏光，油圧と空気圧，24-2（1993），275282.

(8) Brown, F. T. and Nelson, S. E., Trans. ASME, Ser. D, 87-2 (1965), 504-510.

（9）小嶋英一・品田正昭・松井幹雄, 機論, 58-546, B (1992), 356-363.

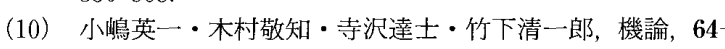
621, C (1998), 1596-1603.

（11）小鴫英一・松原昇・須藤繁, 機論, 61-583, B (1995), 10051013.

（12）小嶋英一一柳隆義, 機論, 61-583, B(1995), 1014-1022. 